\title{
Pengaruh Adverse Selection Dan Negative Framing Terhadap Eskalasi Komitmen Dalam Pengambilan Keputusan Investasi
}

\section{The Effect of Adverse Selection and Negative Framing on Escalation of Commitment in Investment Decision Making}

Siti Zakiyah Hayati Nasution ${ }^{1}$, Rindah Febriana Suryawati ${ }^{1 *}$

1) Departemen Manajemen, Fakultas Ekonomi dan Manajemen, IPB Kampus Dramaga Bogor 16680

\begin{abstract}
Escalation of commitment behavior in investment decision making is an ineffective action by persisting on a project that indicates failure. This study aims to examine whether or not an adverse selection and negative framing effect on the tendency of escalation of commitment. This experimental research uses a $2 \times 2$ factorial design with an instruments of "PT Kue Hebat" case. Participants were Bachelor Degree of Management students who enrolled in Financial Management subject, as substitute for managers whom are chosen by random assignment technique as much as 50 participants. This study uses two ways ANOVA analysis techniques. The results of the study prove that the project manager will show a tendency to escalate commitment by continuing unfavorable projects in adverse selection conditions or in negative framing conditions.
\end{abstract}

Keywords: adverse selection, escalation of commitment, negative framing.

\section{ABSTRAK}

Perilaku eskalasi komitmen dalam pengambilan keputusan investasi merupakan suatu tindakan tidak efektif dengan bertahan pada proyek yang terindikasi gagal. Penelitian ini bertujuan untuk menguji apakah ada atau tidak ada pengaruh adverse selection dan negative framing pada kecenderungan eskalasi komitmen. Penelitian eksperimen ini menggunakan desain faktorial 2 × 2 dengan instrumen dalam bentuk kasus "PT Kue Hebat". Partisipan adalah mahasiswa S1 Manajemen yang telah mengambil mata kuliah manajemen keuangan sebagai bentuk manipulasi dari manajer investasi yang dipilih dengan teknik random assignment sebanyak 50 partisipan. Penelitian ini menggunakan teknik analisis two ways ANOVA. Hasil penelitian membuktikan bahwa manajer proyek akan menunjukkan kecenderungan untuk bereskalasi komitmen dengan melanjutkan proyek yang tidak menguntungkan pada kondisi adverse selection atau pada kondisi negative framing.

Kata kunci: adverse selection, eskalasi komitmen, negative framing.

*Corresponding author

Alamat e-mail: rindah.suryawati@apps.ipb.ac.id 


\section{PENDAHULUAN}

Pengambilan keputusan merupakan salah satu aspek penting dalam fungsi kepemimpinan manajemen. Manajer diharapkan dapat membuat keputusan yang strategis yang dijadikan faktor penentu keberhasilan organisasi di masa depan sehingga menghasilkan keputusan yang optimal. Rasionalitas, realita, logika, dan pragmatis merupakan hal-hal penting yang harus diperhatikan dalam suatu pengambilan keputusan (Soenhadji, 2010). Namun, dalam tindakan pengambilan keputusan seringkali manajer melibatkan rasa ikatan emosional dan rasa tanggung jawab yang kuat dengan keputusan awal yang sudah ditetapkannya. Menurut Kelly dan Milkman (2013), manajer dalam membuat keputusan investasi cenderung meningkatkan perilaku pembenaran diri (self-jutisfication) dengan tetap melanjutkan proyek yang terindikasi gagal dengan menganggap proyek lebih mungkin untuk meningkat setelah mendapatkan umpan balik negatif tentang proyek karena kebutuhan untuk membenarkan keputusan awal agar dapat dianggap tampil baik atau kompeten dalam menyelesaikan proyeknya. Fenomena meningkatkan pembenaran diri dengan tetap melanjutkan proyek tersebut kemudian dinamakan eskalasi komitmen.

Eskalasi komitmen adalah tendensi untuk mempertahankan atau tetap berada dalam tindakan yang tidak efektif pada jangka waktu yang relatif lama (Kreitner \& Kinicki 2012). Menurut Santoso (2012), eskalasi komitmen diartikan sebagai fenomena yang menjelaskan bahwa seseorang tetap meningkatkan atau menambah investasinya, meskipun adanya bukti yang menyatakan bahwa keputusan yang telah diambil merupakan keputusan yang salah. Koroy (2008) mengemukakan eskalasi komitmen ialah suatu keputusan bahwa proyek tetap dilanjutkan walaupun prospek ekonomi proyek tersebut terindikasi harus diberhentikan.

Tendensi seseorang dalam melakukan eskalasi komitmen dipaparkan dalam agency theory. Agency theory memprediksi bahwa ketersediaan informasi dan insentif akan mempengaruhi keputusan manajer Eisenhardt (2009). Ketika manajer mempunyai informasi pribadi dan kesempatan untuk melalaikan tugas utamanya, maka permasalahan seleksi yang merugikan (adverse selection) akan muncul. Manajer (agen) akan bertindak demi kepentingan pribadi dengan mengorbankan kepentingan pemilik. Ketika ada kondisi adverse selection, agen akan melihat perilaku yang tampaknya irasional dalam pandangan pemilik (seperti meneruskan proyek investasi yang tidak menguntungkan) sebagai perilaku yang rasional Eisenhardt (2009).

Menurut Scott (2015) pada kondisi adverse selection, manajer mengetahui lebih banyak tentang keadaan dan prospek perusahaan dibanding pemilik. Fakta-fakta yang mungkin dapat mempengaruhi keputusan yang dapat diambil oleh prinsipal tersebut tidak disampaikan informasinya. Adanya kesempatan untuk memiliki informasi privat dan juga melalaikan tugas tersebut memberikan peluang bagi manajer untuk mengambil keputusan tetap melanjutkan proyek meskipun mengindikasikan kegagalan.

Teori lain yang menjelaskan penyebab terjadinya perilaku eskalasi komitmen adalah teori prospek (prospect theory) yang menyatakan bahwa penyebab terjadinya eskalasi komitmen adalah adanya framing (pembingkaian informasi). Framing ialah titik referensi yang menjadi patokan untuk melakukan perbandingan. Titik referensi tersebut digunakan sebagai frame seseorang untuk melakukan pertimbangan suatu kondisi (Grasiaswaty, 2009).

Manajer dalam melakukan pengambilan keputusan didasari oleh bagaimana informasi tersebut disajikan. Kahneman dan Tversky (2017) dengan prospect theory menjelaskan tentang dimana individu menunjukkan perilaku menghindari risiko (risk averse) ketika keputusan dibingkai secara positif, dan perilaku mencari risiko (risk taker) ketika keputusan dibingkai secara negatif (negative framing). Studi yang dilakukan Arimawan dan Sukirno (2014), membuktikan bahwa negative framing dapat meningkatkan kemungkinan terjadinya eskalasi komitmen ketika hasil proyek disajikan sebagai suatu kerugian yang pasti (negative framing). Salter dan Sharp (2004) juga melakukan eksperimen dengan subjek yang digunakan adalah manajer AS dan Kanada, dan membuktikan bahwa negative framing dapat meningkatkan kemungkinan terjadinya eskalasi komitmen. Alasan-alasan yang sudah dipaparkan diatas memotivasi peneliti untuk melakukan pengujian kembali (confirmatory research) apakah ada pengaruh atau tidak ada 
pengaruh adverse selection dan negative framing terhadap eskalasi komitmen dalam keputusan investasi.

Berdasarkan pemaparan dalam latar belakang, penetilian ini dilaksanakan untuk tujuan: 1) Menguji pengaruh adverse selection terhadap eskalasi komitmen dalam pengambilan keputusan investasi; 2) Menguji pengaruh negative framing terhadap eskalasi komitmen dalam pengambilan keputusan investasi.

\section{METODE PENELITIAN}

Penelitian ini merupakan penelitian eksperimen, yang dilaksanakan di di Departemen Manajemen Institut Pertanian Bogor, dengan melibatkan mahasiswa yang telah memiliki dasar pengetahuan dan pengalaman terkait pengambilan keputusan investasi.

Kerangka pemikiran penelitian disajikan pada Gambar 1 dibawah ini. Proyek investasi yang sedang berlangsung tidak selalu menunjukkan perkembangan yang baik, dimana terkadang ditemukan kondisi dimana proyek yang sedang dijalankan terindikasi kegagalan. Manajer proyek yang bertanggungjawab secara penuh terhadap keberlangsungan proyek yang dijalankannya dihadapkan pada keputusan apakah melanjutkan atau menghentikan proyek yang terindikasi kegagalan. Kelly dan Milkman (2013) menjelaskan bahwa dalam membuat keputusan investasi, manajer cenderung meningkatkan perilaku pembenaran diri dengan tetap melanjutkan proyek yang terindikasi kegagalan dengan menganggap proyek lebih mungkin untuk meningkat setelah mendapatkan umpan balik negatif tentang proyek karena kebutuhan untuk membenarkan keputusan awal agar dapat dianggap tampil baik atau kompeten dalam menyelesaikan proyeknya. Fenomena meningkatkan pembenaran diri dengan tetap melanjutkan proyek tersebut kemudian dinamakan eskalasi komitmen.

Kecenderungan tindakan eskalasi komitmen juga dijelaskan dalam agency theory. Pandangan agency theory tentang eskalasi dikemukakan oleh Scott (2015) dimana pada kondisi adverse selection, manajer mengetahui lebih banyak tentang keadaan dan prospek perusahaan dibanding pemilik. Fakta-fakta yang mungkin dapat mempengaruhi keputusan yang dapat diambil oleh prinsipal tersebut tidak disampaikan informasinya. Adanya kesempatan untuk memiliki informasi privat dan juga melalaikan tugas tersebut memberikan peluang bagi manajer untuk mengambil keputusan tetap melanjutkan proyek meskipun mengindikasikan kegagalan prospect theory. Menurut Kahneman dan Tversky (2017) prospect theory menjelaskan tentang dimana individu menunjukkan perilaku menghindari risiko (risk averse) ketika keputusan dibingkai secara positif, dan perilaku mencari risiko (risk taker) ketika keputusan dibingkai secara negatif (negative framing). Berdasarkan pemaparan tersebut diketahui bahwa kondisi adverse selection yang dipaparkan dalam agency theory dan efek negative framing yang dipaparkan dalam prospect theory dapat memicu tindakan eskalasi komitmen. Penelitian ini akan menguji kembali apakah benar adanya pengaruh adverse selection dan negative framing terhadap eskalasi komitmen dalam pengambilan keputusan investasi dengan menggunakan metode two ways ANOVA. Hasil penelitian dapat diajukan sebagai rekomendasi untuk mencegah kecendrungan eskalasi komitmen dalam pengambilan keputusan investasi. Berikut adalah gambaran kerangka penelitian ini: 


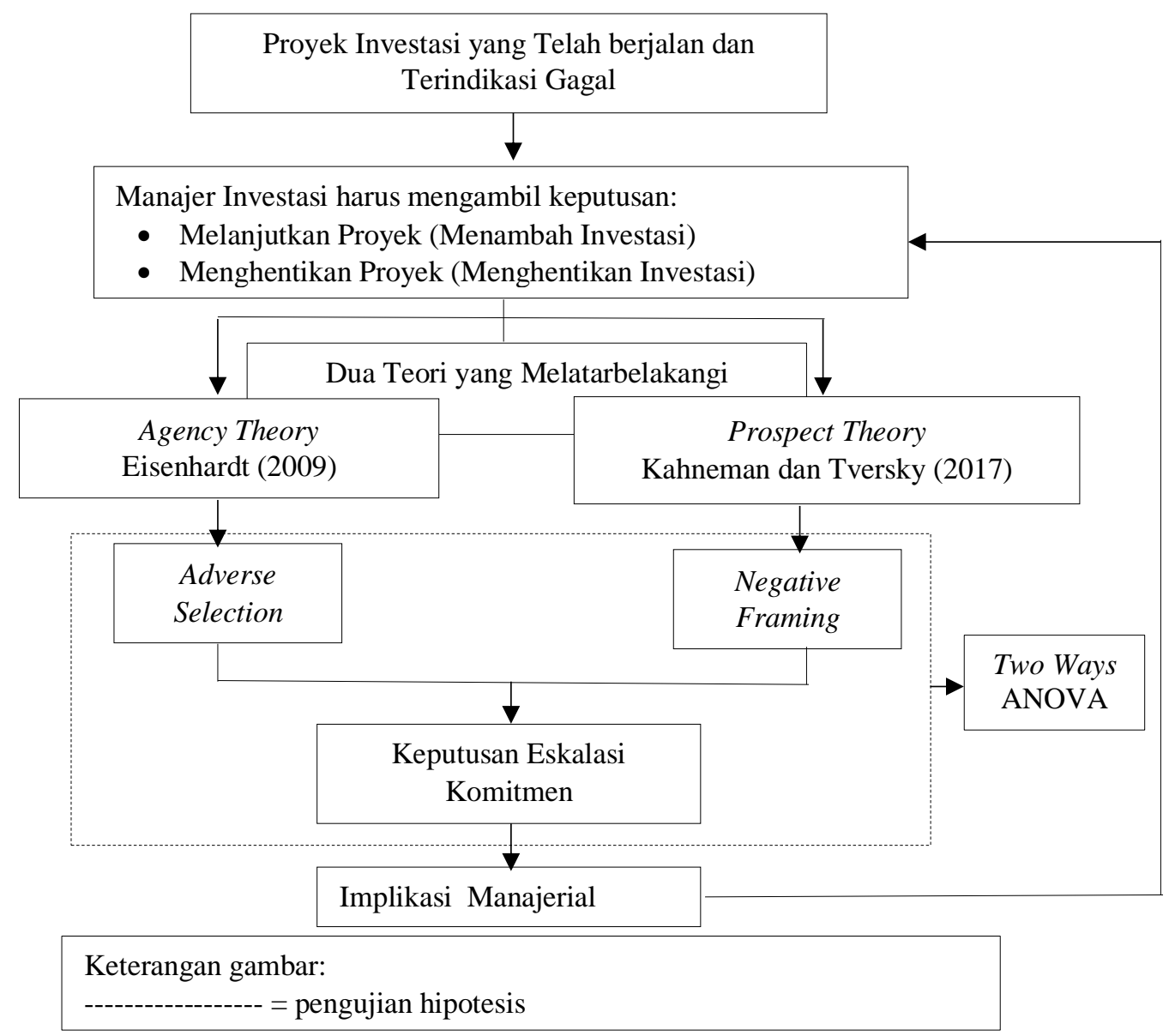

Gambar 1. Kerangka pemikiran

Penelitian ini adalah jenis penelitian eksperimen dengan menggunakan metode analisis two ways ANOVA. Metode penarikan partisipan pada penelitian ini menggunakan random assignment dalam pembentukan kelompok partisipan eksperimen. Menurut Hinkelmann dan Kempthorne (2008) metode random assignment adalah teknik eksperimental untuk menetapkan partisipan ke grup yang berbeda dalam sebuah eksperimen menggunakan pengacakan. Jenis data yang digunakan pada penelitian ini adalah data primer yang diperoleh dengan menggunakan alat bantu kuesioner kasus yang disebar secara langsung dengan desain eksperimen yang digunakan adalah desain faktorial $2 \times 2$ dengan instrumen dalam bentuk kasus yang dibagi menjadi 4 kelompok kasus (kasus A, B, C, dan D). Penelitian ini menggunakan mahasiswa sebagai responden, yang mana mahasiswa tersebut dikondisikan sebagai manajer. Partisipan adalah mahasiswa S1 Manajemen yang telah mengambil mata kuliah manajemen keuangan sebagai bentuk manipulasi dari manajer investasi yang dipilih dengan teknik random assignment sebanyak 50 partisipan. Berikut desain eksperimen penelitian yang tersaji dalam Tabel 1.

Tabel 1. Desain eksperimen faktorial

\begin{tabular}{cccc}
\hline & & \multicolumn{2}{c}{ Adverse Selection } \\
\cline { 2 - 4 } Negative Framing & Ada & Ada & Tidak Ada \\
\hline \multirow{2}{*}{ Tidak Ada } & Kasus B & Kasus C \\
\cline { 2 - 4 } & & & Kasus D
\end{tabular}

Sumber: Data olahan (2018)

Pada Tabel 1 dijelaskan kondisi ada adverse selection dimanipulasi oleh perlakuan A dan $\mathrm{B}$, sedangkan kondisi tidak ada adverse selection dimanipulasi oleh perlakuan C dan D. Kondisi ada negative framing dimanipulasi dalam perlakuan $\mathrm{A}$ dan $\mathrm{C}$, sedangkan kondisi tidak ada negative framing dimanipulasi dalam perlakuan B dan D. 
Instrumen yang digunakan dalam penelitian ini diadopsi dan dimodifikasi dari penelitian Dewanti (2010). Penelitian eksperimen yang dilakukan mengkondisikan semua partisipan sebagai manajer proyek. Mereka menghadapi masalah yang memaksa mereka memutuskan untuk menghentikan atau melanjutkan proyek yang mereka awasi. Partisipan memilih keputusan evaluasi proyek dengan menunjukkan preferensi mereka menggunakan skala likert 1-10. Titik terendah menunjukkan bahwa proyek sangat setuju untuk pasti dihentikan dan titik tertinggi menunjukkan bahwa proyek sangat setuju untuk pasti akan dilanjutkan.

\section{Perumusan Hipotesis}

Fenomena yang terjadi, dimana manajer investasi cenderung melanjutkan proyek yang merugi dalam kondisi private information dari pada dalam kondisi public information telah pula dibuktikan oleh Chong dan Suryawati (2011). Selain itu, penelitian di Indonesia berikutnya yang mendukung temuan ini adalah penelitian Sari dan Wirakusuma (2017) dimana kondisi adverse selection (informasi privat) berpengaruh pada kecenderungan eskalasi komitmen. Namun, masih pula fenomena ini perlu untuk diteliti, mengingat terdapat penelitian lain yang menunjukkan hasil yang berlawanan, yaitu penelitian Helmayunita (2015) dan Dwita (2007) yang menyimpulkan bahwa kondisi adverse selection tidak pengaruh pada kecenderungan untuk melanjutkan investasi pada proyek yang cenderung merugi. Berdasarkan uraian tersebut peneliti menyusun hipotesis pertama yaitu:

H1: Manajer proyek akan menunjukkan kecenderungan untuk bereskalasi komitmen dengan melanjutkan proyek yang tidak menguntungkan di bawa kondisi adverse selection. Menurut Kahneman dan Tversky (2017), prospect theory menjelaskan tentang individu yang menunjukkan perilaku menghindari risiko (risk averse) ketika keputusan dibingkai secara positif, dan perilaku mencari risiko (risk taker) ketika keputusan dibingkai secara negatif (negative framing). Studi yang dilakukan Salter dan Sharp (2004), membuktikan bahwa negative framing dapat meningkatkan kemungkinan terjadinya eskalasi komitmen. Ketika hasil proyek sebagai suatu kerugian yang pasti (negative framing), manajer mempunyai kecenderungan risk taker yaitu tetap bertahan pada proyek tersebut. Pandangan eskalasi komitmen dalam prospect theory ini didukung dengan hasil penelitian Irfan dan Febria (2015) yang menyatakan bahwa manajer yang mendapat perlakuan negative framing cenderung melakukan tindakan eskalasi komitmen dengan melanjutkan proyek investasi yang tidak menguntungkan daripada manajer yang mendapatkan perlakuan tanpa negative framing. Hasil penelitian lainnya berbeda dengan hasil yang ditemukan oleh Amelia (2014) dan Dwita (2007) yang menyatakan bahwa kondisi negative framing tidak berpengaruh terhadap tendensi melanjutkan proyek yang merugikan. Berdasarkan uraian tersebut peneliti menyusun hipotesis kedua yaitu:

$\mathrm{H} 2$ : Manajer proyek akan menunjukkan kecenderungan untuk bereskalasi komitmen dengan melanjutkan proyek yang tidak menguntungkan di bawah kondisi negative framing.

\section{HASIL DAN PEMBAHASAN}

\section{Gambaran Eksperimen}

Sebelum tahapan eksperimen dimulai, peneliti memberikan pengarahan mengenai kasus dan meminta partisipan untuk membaca secara berulang-ulang dan teliti atas kasus yang diberikan. Peneliti juga meminta partisipan untuk menjawab pertanyaan dalam kasus yang diberikan, dengan fokus dan jujur tanpa melihat jawaban partisipan lain karena jawaban kasus tidak memuat jawaban yang benar atau salah. Instrumen yang digunakan dalam penelitian ini berupa kasus PT Kue Hebat. Hasil dari pembagian kuesioner kasus adalah kasus $\mathrm{A}=13$ partisipan, kasus $\mathrm{B}=12$ partisipan, kasus $\mathrm{C}=13$ partisipan, dan kasus $\mathrm{D}=12$ partisipan (total sebesar 50 partisipan).

Penelitian eksperimen ini dilaksanakan dengan melalui beberapa tahapan yang harus dikerjakan partisipan. Terdapat 4 tahapan sebagai berikut:

1. Tahap Pengisian Data Partisipan 
Pada tahapan ini, partisipan mengisikan data diri berupa angkatan kuliah, IPK, jenis kelamin, umur, dan mata kuliah keuangan yang ditempuh.

2. Tahap Treatment

Pada tahapan ini, partisipan diberikan empat kasus dengan jenis yang berbeda yaitu kasus A,

B, C, dan D seperti yang sudah dipaparkan pada desain eksperimen penelitian. Kasus tersebut memanipulasi partisipan sebagai manajer proyek sebuah perusahaan bernama PT Kue Hebat sebagai perusahaan yang sedang menjalankan proyek bolu ubi yang terindikasi gagal. Sebelum partisipan sebagai manajer proyek diminta untuk melakukan pengambilan keputusan untuk melanjutkan atau menghentikan proyek yang terindikasi gagal, partisipan diminta untuk membaca kasus dengan kondisi yang diberikan berbeda-beda pada setiap partisipan yang berbeda pula.

3. Tahap Pengambilan Keputusan

Pada tahap ini, peneliti meminta partisipan untuk memilih diantara dua opsi untuk menghentikan proyek atau melanjutkan proyek yang terindikasi kegagalan. Partisipan memilih keputusan evaluasi proyek dengan melingkari preferensi mereka menggunakan skala 10-poin. Skala 1-5 menunjukkan bahwa proyek setuju untuk dihentikan dimana semakin kecil angka yang dipilih responden maka semakin sangat menyetujui untuk menghentikan proyek. Skala 6-10 menunjukkan bahwa proyek setuju untuk dilanjutkan dimana semakin besar angka yang dipilih responden maka semakin sangat menyetujui untuk melanjutkan proyek.

4. Tahap Manipulation Checking

Manipulation checking pada penelitian ini ditujukan untuk memastikan bahwa partisipan telah berada pada kondisi yang diinginkan sesuai tujuan eksperimen. Pengisian manipulation checking dengan benar menunjukkan bahwa partisipan sadar dan mengerti akan kondisi yang diberikan pada naskah kasus.

\section{Karakteristik Partisipan}

Analisis karakteristik partisipan bertujuan untuk mengetahui bagaimana gambaran karakteristik mahasiswa yang menjadi partisipan penelitian eksperimen. Karakteristik jenis kelamin menunjukkan bahwa responden laki-laki memiliki proporsi lebih rendah dibandingkan dengan responden perempuan. Persentase responden laki-laki sebesar 20 persen sedangkan perempuan sebesar 80 persen. Presentase umur responden terbesar adalah 19 tahun yaitu sebesar 56 persen, kemudian umur 20 tahun sebesar 38 persen, umur 18 sebesar empat persen dan umur 21 sebesar dua persen. Presentase IPK responden terbesar adalan dengan rentang IPK 3,00 - 3,49 yaitu sebesar 54 persen, selanjutnya responden dengan IPK $\geq 3,50$ adalah sebesar 34 persen dan responden dengan IPK 2,50-2,99 adalah sebesar 12 persen.

\section{Uji Validitas}

Menurut Ghozali (2016) penelitian eksperimen memiliki validitas internal lebih besar daripada validitas eksternal. Validitas internal dalam penelitian ini diukur menggunakan jenis validitas face validity. Face validity tercapai apabila pemeriksaan terhadap item-item tes memberi kesimpulan bahwa tes tersebut mengukur aspek yang relevan (Holden, 2010). Peneliti menggunakan teknik face validity dalam mengukur instrumen eksperimen dengan alasan karena kasus yang digunakan dalam penelitian ini mengadopsi dan melakukan sedikit modifikasi dari kasus yang sudah digunakan dalam penelitian terdahulu yaitu penelitian Dewanti (2010) yang sudah diuji validitasnya. Peneliti mengukur instrumen dengan validitas face validity dengan cara meminta pendapat ahli yaitu Ibu Rindah Febriana Suryawati untuk mengkaji instrumen kasus tersebut dan meminta pendapat untuk keperluan revisi. Hasil dari pengukuran face validity instrumen yang dilakukan ada beberapa perbaikan yang berhubungan dengan penggunaan kata dan penjelasan informasi pengisian dalam instrumen kasus agar lebih mudah dipahami oleh partisipan.

\section{Uji Reabilitas}

Penelitian ini menggunakan uji statistik Cronbach Alpha $(\alpha)$ yang menurut Ghozali (2016) suatu konstruk atau variabel dikatakan reliabel jika nilai Cronbach Alpha $>0,600$. Hasil uji 
reliabilitas instrumen yang dipakai dalam penelitian ini menunjukkan nilai Cronbach Alpha sebesar 0,632. Nilai tersebut menunjukkan bahwa instrumen yang dipakai dalam penelitian ini adalah reliabel.

\section{Uji Homogenitas}

Tests of homogeneity of variance dilakukan untuk mengetahui apakah keempat kelompok (Kasus A, B, C, dan D) mempunyai varian yang sama. Hasil uji statistik menunjukkan nilai levene statistic sebesar 0,544 jauh diatas 0,05. Hal ini menunjukkan bahwa setiap kelompok subjek memenuhi varian yang sama sehingga telah memenuhi asumsi ANOVA (Hair et al 2014).

\section{Uji Two Ways Analysis of Variance (ANOVA)}

Setelah dilakukan pengujian hipotesis menggunakan metode analisis two-ways ANOVA, maka diperoleh hasil:

1. H1: Manajer proyek akan menunjukkan kecenderungan untuk bereskalasi komitmen dengan melanjutkan proyek yang tidak menguntungkan di bawah kondisi adverse selection.

Hasil pengujian hipotesis pertama memberikan bukti bahwa adverse selection berpengaruh pada kecenderungan eskalasi komitmen dengan p-value 0,023 $(<0,05)$. Hasil penelitian mampu menunjukkan ketika dihadapkan pada kondisi adverse selection, manajer cenderung melakukan eskalasi komitmen. Dengan demikian, penelitian ini membuktikan bahwa private information yang dimiliki oleh manajer ketika terjadi asimetri informasi dengan principal yang dipaparkan dalam teori keagenan, hal tersebut dapat memengaruhi tindakan manajer yang tidak sesuai dengan kepentingan perusahan dan tidak memaksimalkan keuntungan perusahaan.

2. H2: Manajer proyek akan menunjukkan kecenderungan untuk bereskalasi komitmen dengan melanjutkan proyek yang tidak menguntungkan di bawah kondisi negative framing.

Hasil pengujian hipotesis kedua menunjukkan bahwa negative framing berpengaruh pada kecenderungan eskalasi komitmen dimana $p$-value yang dihasilkan adalah $0,010(<0,05)$. Hasil penelitian memberikan bukti penyajian informasi secara negative framing manajer cendeung untuk melakukan eskalasi komitmen. Hasil ini menunjukkan bahwa manajer akan cenderung melanjutkan proyek tidak menguntungkan jika informasi disajikan secara negatif.

Hasil penelitian menunjukkan terdapat pengaruh adverse selecion terhadap kecenderungan eskalasi komitmen. Hasil tersebut ditunjukkan dengan nilai $p$-value $0,023(<0,05)$ yang memiliki makna bahwa jika manajer yang memiliki informasi privat (kondisi adverse selection) akan cenderung meningkatkan eskalasi komitmennya. Penelitian ini konsisten dengan penelitian Chong dan Suryawati (2011) yang menyatakan bahwa seorang manajer proyek akan menunjukkan kecenderungan yang lebih besar untuk melanjutkan sebuah proyek yang tidak menguntungkan di bawah kondisi informasi privat daripada di bawah kondisi informasi yang dipublikasi. Penelitian ini juga konsisten dengan studi yang dilakukan Sari dan Wirakusuma (2017) menyatakan bahwa ketika dihadapkan dalam kondisi adverse selection (informasi privat), maka keinginan pengambil keputusan untuk bereskalasi komitmen cenderung meningkat. Dengan demikian penelitian ini membantah hasil penelitian dari Helmayunita (2015) dan Dwita (2007) yang menyatakan tidak terdapat pengaruh kondisi adverse selection terhadap keputusan eskalasi komitmen manajer.

Hasil penelitian juga membuktikan bahwa terdapat pengaruh negative framing terhadap tendensi eskalasi komitmen. Hasil tersebut ditunjukkan dengan nilai $p$-value $0,010(<0,05)$ yang memiliki makna bahwa ketika informasi dibingkai secara negatif (negative framing) manajer cenderung melakukan tindakan eskalasi. Penelitian ini konsisten dengan pandangan prospect theory. Kahneman dan Tversky (2017) menjelaskan tentang prospect theory dimana individu menunjukkan perilaku menghindari risiko (risk averse) ketika keputusan dibingkai secara positif, dan perilaku mencari risiko (risk taker) ketika keputusan dibingkai secara negatif (negative framing). Dengan demikian manajer yang mendapat pembingkaian negatif dan cenderung melakukan eskalasi komitmen merupakan manajer yang memiliki sifat risk taker. Hasil penelitan juga mendukung hasil penelitian Irfan dan Febria (2015) yang menyatakan bahwa manajer yang mendapat perlakuan negative framing cenderung melakukan tindakan eskalasi komitmen dengan 
melanjutkan proyek investasi daripada manajer yang mendapatkan perlakuan tanpa negative framing. Dengan demikian penelitian ini membantah hasil penelitian dari Amelia (2014) dan Dwita (2007) yang menyatakan bahwa kondisi negative framing tidak berpengaruh terhadap tendensi melanjutkan proyek yang merugikan.

\section{Implikasi Manajerial}

Hasil penelitian dan pengolahan data yang telah dilakukan menunjukkan bahwa manajer cenderung melakukan eskalasi komitmen dikarenakan adanya kondisi adverse selection. Kondisi tersebut terjadi jika kondisi informasi tentang kinerja proyek bersifat privat karena hanya dimiliki oleh manajer investasi sehingga manajer dapat melakukan penyeleksian informasi yang akan disampaikan kepada pemilik. Akibatnya, jenis informasi seperti performa proyek yang mulai memburuk menciptakan peluang bagi manajer untuk melalaikan tugas dalam memenuhi kepentingan pribadinya yang berlawanan dengan kepentingan pemilik.

Permasalahan seperti adverse selection yang menjadi salah satu pemicu manajer proyek untuk melakukan tindakan eskalasi komitmen merupakan salah satu tantangan besar yang dihadapi oleh perusahaan. Penelitian ini memberikan saran dengan cara mengaitkan fungsi manajemen menurut (Robbins \& Coulter, 2016) yaitu merencanakan, mengorganisasi, mengarahkan, dan mengendalikan dengan upaya pencegahan tindakan eskalasi komitmen. Berikut implikasi manajerial penelitian:

1. Fungsi perencanaan, perusahaan diharapkan memiliki perencanaan yang baik sebelum memulai menjalakan suatu proyek. Perencanaan yang baik dapat berupa seperti menetapkan apakah proyek memerlukan pengawasan dari pihak lain yang ditentukan oleh perusahaan serta perencanaan pemberlakuan reward dan punishment yang tepat bagi manajemen pelaku pelaksana proyek. Hal tersebut merupakan langkah awal pencegahan manajer melakukan tindakan menyimpang seperti penyeleksian informasi (kondisi adverse selection). Pemberian reward yang tepat dapat memicu manajemen memberikan kinerja terbaiknya dalam menjalankan proyek yang diberikan. Pemberian reward dapat berupa pemberian insentif, bonus atau remunerasi yang memadai. Sedangkan pemberian punishment (ancaman bahkan hukuman) terhadap manajemen yang berperilaku menyimpang dan merugikan pemilik bisa dilakukan untuk mengatasi permasalahan adverse selection. Hukuman yang diberikan oleh pemilik bisa berupa pemecatan, merotasi atau memindahkan tempat kerja dan posisi seseorang ketempat dan posisi yang lebih rendah. Pencegahaan perilaku eskalasi komitmen dengan ancaman berupa rotasi pekerjaan (job rotation) ini juga dibuktikan oleh penelitian Chong dan Suryawati (2011) yang menyatakan bahwa manajer proyek cenderung tidak melakukan tindakan eskalasi komitmen pada proyek yang terindikasi gagal ketika kebijakan job rotation diterapkan oleh perusahaan.

2. Fungsi pengorganisasian, perusahaan diharapkan mampu menetapkan sumber daya manusia yang memiliki keahlian yang sesuai dengan bagian-bagian dalam manajemen yang menjalankan proyek. Selain itu, sumber daya manusia yang ditetapkan dalam departemen pengawasan proyek harus bersifat objektif dan independen sehingga manajer yang memiliki potensi untuk melakukan tindakan penyimpangan dapat digagalkan karena terawasi dengan baik.

3. Fungsi pengarahan, perusahaan yang sebelumnya merencanakan untuk melakukan penetapan departemen pengawasan terhadap proyek harus mampu mengarahkan departemen tersebut agar bekerja dengan teliti dan baik sehingga tidak ada celah bagi manajer untuk melakukan penyimpangan.

4. Fungsi pengendalian, asimetri informasi dan upaya melalaikan tugas dapat diatasi dengan cara melakukan pengawasan yang baik pada kebijakan dan aktivitas manajemen perusahaan. Perusahaan harus memiliki departemen yang secara khusus dapat mengawasi kelangsungan proyek yang dijalankan manajemen. Dengan adanya pengawasan tersebut maka akan menghinadari adanya potensi agen (manajemen) yang menyembunyikan informasi. Hal ini membenarkan penelitian Chong dan Suryawati (2010) bahwa penerapan monitoring control akan mengurangi kecenderunagn eskalasi komitmen dimana perusahaan harus memiliki 
Departemen Evaluasi Proyek yang memiliki peran untuk mengevaluasi keputusan manajer investasi terkait proyek investasi yang mereka rintis dan kelola.

\section{KESIMPULAN}

Kesimpulan yang dihasilkan penelitian ini, yaitu adverse selection berpengaruh terhadap eskalasi komitmen dalam pengambilan keputusan investasi. Hasil ini dapat diartikan bahwa ketika manajer diberi kondisi adverse selection dimana terjadi asimetri informasi antara manajer yang cenderung memiliki informasi privat dan pemilik yang tidak mengetahui informasi internal manajemen, memicu keinginan pengambil keputusan (manajer) untuk bereskalasi komitmen. Hasil penelitian juga menunjukkan negative framing berpengaruh pada kecenderungan eskalasi komitmen. Pengambil keputusan memiliki tendensi meningkatkan eskalasi komitmennya ketika informasi disajikan dalam negative framing.

\section{DAFTAR PUSTAKA}

Amelia, Y. (2014). Framming Effect sebagai Determinan Eskalasi Komitmen Manajer dalam Keputusan Investasi: Dampak dari Latar Belakang Pendidikan Akuntansi dan Non Akuntansi [Internet].[diunduh Juni 2018]. Tersedia pada: repository.lppm.unila.ac.id/1758/1/110-13-269-1-10-20170520.pdf.

Arimawan, M. S., \& Sukirno. (2014). Pengaruh Negative Framing dan Adverse Selection Terhadap Eskalasi Komitmen [Internet].[diunduh Juni 2018]. Tersedia pada: https://journal.uny.ac.id/index.php/nominal/article/view/2150/1788.

Chong, V. K., \& Surwayati, R. F. (2010). De-escalation strategis: The Impact of Monitoring Control on Managers' Project Evaluation Decisions [Internet].[diunduh Juni 2018]. Tersedia pada: https://cmawebline.org/images/stories/JAMAR_2010_Summer/JAMARv8.2-DeEscalation_Strategy.pdf

(2011). The Effect of Job Rotation Policy in Preventing Managerial Escalation of Commitment [Internet].[diunduh Juni 2018]. Tersedia pada: https://doi.org/10.1504/IJAAPE.2011.040833.

Dewanti, R. (2010). Pengaruh Negative Framing dan Job Rotation pada Kondisi Adverse Selection terhadap Pengambilan Keputusan Eskalasi Komitmen. Semarang: Universitas Diponegoro.

Dwita, S. (2007). The Influence of Adverse Selection and Negative Framing on Escalation of Commitment in Project Evaluation Decisions. Simposium Nasional Akuntansi X. Makassar.

Eisenhardt, K. M. (2009). How Management Teams Can Have a Good Fight. Massachusetts: Harvard Business School Press.

Ghozali, I. (2016). Aplikasi Analisis Multivariate Dengan Program IBM SPSS 23. Semarang: Penerbit Universitas Diponegoro. Ed ke-8.

Grasiaswaty, N. (2009). Fenomena Framing di Balik Diskon Besar-besaran [Internet].[diunduh Juni 2018]. Tersedia pada: http://ruangpsikologi.com.

Hair, J. F., Black, W. C., Babin, B. J., \& Anderson, R. E. (2014). Multivariate Data Analysis. New Jersey: Pearson Education. 7th ed.

Helmayunita, N. (2015). Pengaruh Adverse Selection, Kontrol Monitoring, Dan Penalaran Moral Individu Terhadap Perilaku Eskalasi Komitmen [Internet].[diunduh Juni 2018]. Tersedia pada: ejournal.unp.ac.id/index.php/wra/article/view/6158.

Hinkelmann, K., \& Kempthorne, O. (2008). Design and Analysis of Experiments. New York: John Wiley \& Sons. 2nd ed.

Holden, R. B. (2010). The Corsini Encyclopedia of Psychology. Weiner IB, Craighead WE, editor. New York: John Wiley \& Sons. 4th ed.

Irfan, A., \& Febria, D. (2015). Negative Framing, Rigid Thinking and The Escalation of Commitment on Decision Making: Experimental Study [Internet].[diunduh Juni 2018]. Tersedia pada: 
apexjournal.org/jbamsr/archive/2015/Mar/fulltext/Irfan\%20and\%20Febria.pdf.

Kahneman, D., \& Tversky, A. (2017). Choices, Values, and Frames. Cambridge: Cambridge University Press.

Kelly, T. F., \& Milkman, K. L. (2013). Encyclopedia of Management Theory. Kessler EH, editor. Thousand Oaks: Sage Publications.

Koroy, T. R. (2008). Pengujian Efek Pembingkaian Sebagai Determinan Eskalasi Komitmen Dalam Keputusan Investasi: Dampak Dari Pengalaman Kerja. Simposium Nasional Akuntansi XI. Pontianak.

Kreitner, R., \& Kinicki, A. (2012). Orgaizational Behavior. New York: McGraw-Hill Higher Education. 8th ed.

Robbins, S. P., \& Coulter, M. (2016). Manajemen. Jakarta: PT Indeks. Ed ke-13.

Salter, S. B., \& Sharp, D. J. (2004). The Determinants of Escalation Commitment: National Culture and Experience Effects.

Sari, N. K. A. P., \& Wirakusuma, M. G. (2017). Pengaruh Adverse Selection dan Negative Framing pada Kecenderungan Eskalasi Komitmen [Internet]. [diunduh Juni 2018]. Tersedia pada: https://doi.org/10.24843/JIAB.2017.v12.i01.p01.

Santoso, A. B. (2012). Peranan Locus of Control,Self-Set dan Organizational-Set Hurdle Rates terhadap Eskalasi Komitmen pada Level Pengambilan Keputusan Penganggaran Modal. Jurnal Ilmiah Mahasiswa Akuntansi.

Scott, W. R. (2015). Financial Accounting Theory. Ontario: Prentice-Hall.

Soenhadji, I. M. (2010). Teori Pengambilan Keputusan. Jakarta: Universitas Gunadarma. 